\title{
CLASS STRUCTURE AND POLITICAL IDEOLOGY
}

\section{VAL BURRIS}

Marxist theorists have devoted much effort recently to the clarification of the concept of class and the elaboration of alternative models of class structure. The main focus of this theorizing has been the class position of salaried intermediaries and their role in the class struggle. With a few exceptions, most Marxists today recognize the existence in advanced capitalist society of a significant group of people who cannot be included in the working class, even though they work for a salary or wage. Various names have been applied, to this group- "new middle class," "new petty bourgeoisie," or "professional-managerial class" - and competing theories have been advanced to explain the nature and significance of these positions within the class structure. Disagreements over how to conceptualize intermediate class positions have prompted extensive debates over the basic principles of Marxist class analysis and the application of those principles to modern capitalist society.

Three issues have been central to this debate. First is the definitional question of specifying the boundaries of classes - especially the boundary which separates intermediate class positions from the working class. Second is the conceptual issue of clarifying the nature and identity of these intermediate class positions. Do they qualify as a "class" in the full sense of the term? If so, do they constitute a new class within advanced capitalism or the evolution of some earlier intermediate class? Third is the political question of predicting the alignment of this group in the struggle between capital and labor. Will it side with the proletariat or the bourgeoisie, establish an independent third course, or fragment under the strain of competing pressures?

On the question of class boundaries, at least four different lines of demarcation have been proposed to distinguish intermediate from proletarian class positions. The first and most restrictive definition of the proletariat assigns a nonproletarian status to all salaried employees except manual workers in industry. The second identifies the boundary between proletarian and nonproletarian positions as a division between manual and nonmanual workers. The third excludes only professionals and managers from the proletariat. The fourth excludes only managers who directly supervise other workers. 
On the question of the identity of these intermediate positions, three alternative theories can be distinguished. The first interprets these positions as a heterogeneous intermediate stratum which lacks the coherence or unity of a true class. The second and third perspectives attribute a common class identity to these positions - one viewing them as a new middle class and the other seeing them as an extension of an older intermediate class, the petty bourgeoisie.

Distinctive conceptions of political strategy are associated with different models of class structure. Theorists who classify the vast majority of wage workers as members of the proletariat tend to favor an parliamentary strategy of socialist transition based on the preponderant numerical strength of the working class. Those who adopt a narrower definition of the working class are more likely to affirm the necessity of an extraparliamentary strategy and/or to identify the prospects for socialism with the possibility of alliances between the proletariat and other classes. Different conceptions of the identity of intermediate classes yield different conclusions regarding the possibility of such alliances. Theorists who interpret these intermediate positions as part of a heterogeneous stratum usually characterize this group as incapable of independent political organization and therefore open to the competing political appeals if the proletariat and the bourgeoisie. Because they view this group as having no unifying class interests antagonistic to those of the proletariat, they perceive few barriers to the incorporation of large segments of this stratum into a popular alliance with the working class. Theorists who view these intermediate positions as belonging to a separate class are usually more skeptical about the possibility of class alliances. This is particularly true of those who identify these intermediate positions as a fraction of the traditional petty bourgeoisie - a class which is associated historically with fascism and other reactionary right-wing movements. Such theorists typically place a greater emphasis on the working class as the leading force in the transition to socialism, regarding all other classes as, at best, temporary or unstable allies in this struggle. The question of how to conceptualize intermediate class positions is therefore of more than theoretical interest; it poses issues which go to the very heart of socialist political strategy.

In this paper I examine the question of intermediate class positions from both a theoretical and an empirical direction. The first part of the paper presents a critical overview of alternative Marxist theories of class structure. Five specific theories are examined: Nicos Poulantzas' theory of the new petty bourgeoisie, Erik Olin Wright's theory of contradictory class locations, Wright's more recent theory of class structure 
and exploitation, Guglielmo Carchedi's theory of the new middle class, and Barbara and John Ehrenreich's theory of the professional-managerial class. In the conclusion of the paper I outline the model of class structure which, for both theoretical and empirical reasons, I believe best captures the existing pattern of class relations in American society.

\section{Poulantzas: The New Petty Bourgeoisie}

Few theorists have exercised greater influence over the development of Marxist class analysis than Nicos Poulantzas. Indeed, much of the recent Marxist debate over the class location of salaried intermediaries has been directly inspired by Poulantzas' theory of the "new petty bourgeoisie" and the broader principles of class analysis upon which that theory is based.

Poulantzas' analysis of class rests on several basic premises. First, Poulantzas argues that classes cannot be defined apart from class struggle. By this Poulantzas emphasizes the relational nature of classes: classes refer neither to positions within a static classificatory scheme nor to groups of similar individuals composed through simple addition, but to the system of antagonistic relations which comprise the social division of labor. Second, classes are structurally determined; they exist objectively, independent of the will or consciousness of individuals. Class analysis is therefore concerned with the structure of "empty places" within the social division of labor, and only secondarily with the identity of the social agents who occupy such places. Third, in the determination of classes, the principal role is played by the social relations of production. By this, Poulantzas distinguishes the Marxist theory of class from those who define classes in terms of the social relations of distribution (income categories) or who derive classes from the technical organization of production (occupational categories). Finally, while the economic place of social agents has the principal role in defining classes, Poulantzas maintains that political and ideological relations are also part of the structural determination of class. In Poulantzas' model of class structure there are thus three criteria-economic, political and ideological - which define the boundary between proletarian and nonproletarian class positions.

In analyzing the economic determinants of class, Poulantzas rejects the criterion of wage-labor (nonownership of the means of production) as a sufficient condition of proletarian class position. The wage relation, Poulantzas argues, is a form of distribution of the social product rather than a social relation of production. Ownership or nonownership of the means of production acquire significance only insofar as they 
correspond to determinate relations of exploitation. In place of wagelabor, Poulantzas substitutes the criterion of productive labor (labor which produces surplus value) as the distinctive economic characteristic of the working class. Productive labor is defined narrowly by Poulantzas to include only that labor which directly produces surplus value through the production of material commodities, thereby excluding service workers as well as state and commercial workers from the working class. Wage-earners in these sectors are considered to be outside of the dominant capitalist relation of exploitation and are therefore classified as part of a separate class, the "new petty bourgeoisie."

The political and ideological determinants of class serve to exclude further positions from the proletariat. By political and ideological relations, Poulantzas refers to those social relations which secure the reproduction of the dominant mode of exploitation. At the political level this is accomplished through the relations of supervision and authority within the capitalist enterprise. According to Poulantzas, the work of management and supervision under capitalism entails not only the technical coordination of the labor process, but also the enforcement of capitalist domination over the working class. This 'places salaried managers and supervisors in an antagonistic relation to the working class, even when they are engaged in productive labor. At the ideological level Poulantzas identifies the basic class relation as the division between mental and manual labor. Poulantzas argues that this division also reproduces the subordination of the working class by excluding them from the "secret knowledge" of the production process and thereby reinforcing their dependence upon capital. Professionals, technicians and other mental workers are the bearers of this relation of ideological domination and are therefore classified as part of the new petty bourgeoisie along with managers and supervisors.

The new petty bourgeoisie is thus defined by Poulantzas as those salaried workers who are not exploited in the form of the dominant capitalist economic relation (unproductive workers) or who participate in the domination of the working class either politically (managers, supervisors) or ideologically (mental workers). Comparing these intermediate positions to those of the traditional petty bourgeoisie (small shopkeepers, artisans), Poulantzas concludes that the two groups are both part of a single heterogeneous class, the petty bourgeoisie. Even though they occupy different structural positions, the traditional and the new petty bourgeoisie are similarly located in relation to the dominant class antagonism between the proletariat and the bourgeoisie. This common situation within the class struggle results in a rough ideological unity, 
characterized by competitive individualism, reformism, and a belief in the neutrality of the state as an arbiter of competing class interests. Poulantzas maintains that this ideological affinity is sufficiently strong to justify placing both the traditional and the new petty bourgeoisie in the same class.

Numerous criticisms have been raised against Poulantzas' model of class structure (Wright, 1976; 1980; Hunt, 1977; Skotnes, 1979). Probably the most controversial aspect of Poulantzas' theory is his use of productive labor as a criterion of proletarian membership. Apart from the arbitrariness of Poulantzas' restriction of productive labor to those who produce surplus value in material goods production only, the productive/unproductive distinction is problematic as a boundary between classes since, by any definition, most concrete positions within the social division of labor combine a mix of productive and unproductive activities. More important, it is not clear why the distinction between productive and unproductive labor should correspond to any fundamental differences in worker interests or experience. It is true that some unproductive workers are exempt from exploitation. But most unproductive workers are exploited no less than productive workers; only the mechanism of their exploitation differs. The labor of productive workers is expropriated in the form of surplus value; that of unproductive workers is expropriated in the form of unpaid labor time which reduces the cost to the capitalist of appropriating part of the surplus value produced elsewhere (Marx, 1967:300). For most routine commercial and clerical workers the concrete experience of exploitation is essentially identical to that of productive workers. In both cases workers are engaged in an antagonistic relation with capitalists over the rate of exploitation and control of the labor process. If, as Poulantzas argues, classes are defined by their position in the class struggle, it is difficult to see why unproductive labor should be a sufficient condition for exclusion from the proletariat.

Further objections can be raised against Poulantzas' interpretation of the political and ideological determinants of class position. While it makes sense to view the monopolization of productive knowledge as a form of class domination, thereby placing those who monopolize such knowledge in an antagonistic relation to the working class, it does not follow that all mental workers, including routine clerical and commercial employees, should be placed in this category. As Braverman (1974:293376) has documented, the labor processes in many offices and commercial enterprises are just as rationalized, as despotically controlled, and as mechanized as those of industry. The fact that routine mental workers 
participate in certain "rituals" and "cultural practices" which symbolize their ideological distance from manual workers does not demonstrate their domination over those workers, particularly when they themselves are no less separated from the knowledge necessary for the direction of the production process.

Finally, the fact that political and ideological criteria override the importance of economic criteria in Poulantzas' model draws into question his assertion of the primacy of economic relations over political and ideological relations. Salaried managers and technicians who share with workers the common economic practice of productive labor are excluded from the working class solely on the basis of political and ideological criteria. Conversely, the traditional and the new petty bourgeoisie, which occupy different economic positions, are classified as part of a single class on the basis of "common ideological effects." The unity which Poulantzas attributes to the traditional and the new petty bourgeoisie is especially problematic, since the economic positions occupied by these classes are not only divergent but objectively antagonistic. The concentration and centralization of capitalist enterprise, upon which the growth of the new petty bourgeoisie is based, poses a vital threat to the petty commodity forms of production from which the traditional petty bourgeoisie derives its livelihood. Given the opposed economic interests of these two groups, their fusion into a single class on the grounds of common ideological tendencies contradicts the fundamental Marxist premise of the primacy of economic relations in the determination of classes.

\section{Wright: Contradictory Class Locations}

One of the most rigorously developed alternatives to Poulantzas' theory of the class structure is Erik Olin Wright's theory of contradictory class locations. Like Poulantzas, Wright $(1980 ; 325)$ begins by setting out the basic theoretical premises of the Marxist conception of class. First, classes are defined in relational rather than gradational terms. Second, classes are determined by the social organization of economic relations rather than the technical organization of economic relations. Third, within the social organization of economic relations, classes are defined by the social relations of production rather than the social relations of exchange. In contrast to Poulantzas, Wright excludes political and ideological relations from the structural determination of class position, although he views these as important factors in determining the concrete alignment of class positions within the class struggle. 
In Wright's model, class positions are defined by three economic criteria: control over investments and resource allocation, control over the physical means of production, and control over labor. The first of these designates the relations of "real economic ownership" (as opposed to mere legal ownership); the second and third comprise what Wright calls the economic relations of "possession." In terms of this model, the fundamental class division between capital and labor is viewed as a polarized, antagonistic relation in which the capitalist class occupies a dominant position (full control) and the working class a subordinate position (no control) on all three of these dimensions. These constitute the two basic classes of the capitalist mode of production. In addition, Wright recognizes a third class - the traditional petty bourgeoisie - which is distinguished by its location in a different mode of production: the petty commodity mode of production. Petty bourgeois positions involve both real economic ownership and control over the physical means of production, but not control over the labor of other workers, since none are employed. All remaining positions for which the three dimensions of class relations do not coincide perfectly are classified by Wright as "contradictory class locations," i.e., as social positions that are not firmly rooted in any single class, but occupy objectively contradictory locations "between" classes.

Wright identifies three groups of contradictory locations. Managers and supervisors occupy a contradictory location between the working class and the capitalist class. Like workers they are excluded from control over investments and resource allocation, but like capitalists they exercise a degree of control over the physical means of production and over the labor of others. Semi-autonomous employees occupy a contradictory location between the working class and the petty bourgeoisie. Like the working class they are excluded from both the control over investment capital and over the labor of others, but like the petty bourgeoisie they retain a degree of control over their immediate physical means of production within the labor process. Small employers occupy a contradictory location between the petty bourgeoisie and the capitalist class since they employ and control a minimal amount of labor power, but not sufficient to accumulate large masses of capital. Each of these groups combines characteristics of two classes and is therefore viewed as being objectively torn between two opposing class locations.

As a general strategy for conceptualizing the class position of salaried intermediaries, Wright's notion of "contradictory class locations" is appealing. It captures the ambiguity of these class locations as well as the complexity of their relationship to other classes. The particular criteria 
by which Wright defines these contradictory locations, however, are open to criticism. Although presented in Marxist terms, Wright's model, draws upon a Weberian conception of occupational stratification as much as a Marxist conception of class relations. This can be seen by comparing Wright's model with his own statement of the basic premises of Marxist class analysis. Wright maintains that classes must be analyzed in terms of the social relations of production rather than the technical organization of production; however, his own criteria of class position are specified essentially in terms of the technical characteristics of occupational positions: which activities and decisions they participate in, how much autonomy they exercise, etc. Wright also maintains that, in order to grasp the class contradictions which motivate social change, classes must be defined in relational rather than gradational terms; yet, he immediately proceeds to define classes in terms of forms of control that are inherently gradational. Control over investments, control over the physical means of production and control over the labor process are inherently matters of degree, as Wright (1980:332) himself recognizes by specifying four general levels of control for each of these dimensions: "full control," "partial control," "minimal control," and "no control." The result is that, logically, Wright's criteria imply an indeterminate number of contradictory class locations, stratified along three separate dimensions, with no meaningful line of demarcation between them and the "noncontradictory" positions of the basic classes. In his pursuit of a rigorous system of classification, Wright defines classes virtually out of existence, since, by his own estimates, as much as 56 per cent of the U.S. labor force does not belong to any particular class, but is located somewhere outside of or between the three basic classes (Wright, 1976:37).

These problems are most pronounced in Wright's treatment of salaried intermediate positions - especially the contradictory class location which he refers to as "semi-autonomous employees." First, there is the question of why these positions should be located between the proletariat and the petty bourgeoisie while managers and supervisors are located between the proletariat and the capitalist class. In terms of his three criteria of class position, semi-autonomous employees could just as well be viewed as combining characteristics of the proletariat and the bourgeoisie. Wright suggests that semi-autonomous employees represent an historical residuum of formerly petty-bourgeois positions which, although they now work for a salary, have not yet been fully proletarianized under capitalist relations of production. Yet, this is hardly an accurate description of the majority of salaried professional and technical positions which only came into existence with the growth of capitalism, and 
is probably more true of many salaried managers (e.g., managers in retail trade, farm managers, etc.) which Wright locates between the proletariat and the bourgeoisie even though they did indeed originate out of the expansion of capitalism into previously petty-bourgeois domains.

Second, since Wright defines autonomy as a technical relationship between workers and their physical means of production, his model fails to specify any social relationship between those who possess a certain level of autonomy and those who do not. The boundary between the working class and semi-autonomous employees is therefore merely a point on a scale, not a division between two groups of class positions which are defined by their antagonistic relation to one another. In this regard, Poulantzas' concept of the monopolization of strategic knowledge would seem to provide a sounder basis for identifying the class interests of nonsupervisory mental workers, even if Poulantzas himself applies this concept much too widely.

Finally, of Wright's three dimensions of control, the criterion of autonomy is most obviously a gradational characteristic. Virtually all workers retain at least some control over their immediate instruments of production. At what point does their level of control become sufficient to exclude them from the working class? Certainly the industrial workers of Marx's day exercised, by contemporary standards, a considerable degree of control over the labor process. Does this mean that they were not proletarians? The problem here is not just one of a degree of indeterminacy in the application of the autonomy criterion, since any definition of class boundaries will confront ambiguous or borderline cases, but the fact that the criterion in question implies no logical basis for drawing the boundary at one point rather than another. To operationalize the autonomy criterion, Wright (1978:82) proposes that sufficient autonomy exists to warrant exclusion from the working class whenever an employee exercises some control over what is produced, and not merely over how it is produced, but this dividing line is never defended theoretically, nor is there any explanation offered as to why distinctive class interests should be associated with the first form of autonomy and not the latter.

\section{Wright: Class Structure and Exploitation}

In his more recent writings, Wright (1985) himself has raised a number of objections to his original theory of contradictory class locations and suggested an alternative approach to the analysis of salaried intermediate classes. The basic problems with his earlier theory, Wright now argues, derive from its misguided attempt to incorporate relations of 
domination and subordination into the Marxist definition of class - an error which it shares with other contemporary Marxist theories of class structure. From a Marxist standpoint, Wright argues, the introduction of class criteria like the exercise of supervisory authority or autonomy from such authority creates two kinds of problems. First, such relations do not, in and of themselves, imply any necessary asymmetry of class interests. This is a problem I have already noted in my critique of Wright's criterion of autonomy. In Wright's view, however, it is a deficiency common to all criteria of class position which are framed in terms of relations of domination and subordination. Second, Wright argues that incorporating relations of domination and subordination into the definition of class obscures the distinctiveness of class oppression by placing it on the same plane as numerous other forms of dominationsexual, racial, national, etc. This renders problematic the basic Marxist claim of the explanatory primacy of class relations in social and historical analysis.

In order to overcome these problems, Wright now argues that class must be conceptualized exclusively as a relationship of exploitation, rather than a complex unity of exploitation and domination relations. Building upon the work of John Roemer (1982), Wright maintains that exploitation (the transfer of labor from one class or individual to another) is essentially a product of the unequal distribution of property rights in the means of production. Relations of domination and subordination at the point of production may enhance or reinforce such exploitation, but they are basically incidental to its operation. In any society it is possible to distinguish multiple forms of exploitation. The dominant form of exploitation in capitalist society is that based on the private ownership of the material means of production, but there are also subsidiary forms of exploitation which derive from the unequal distribution of other productive assets. One such asset is skills - especially those whose supply is artificially restricted through credentials. A second is what Wright calls "organization assets," by which he means control over the conditions for the coordination of labor. Within this framework, salaried intermediaries are distinguished from the working class by their ownership of one or the other (or both) of these subsidiary assets. Such differentials in skill and organization assets, Wright argues, enable them to exploit the labor of other workers, even as they themselves are exploited by capitalists.

This new theory of class structure has important continuities with Wright's earlier theory of contradictory class locations. The class location of salaried intermediaries can still be viewed as "contradictory" in 
the sense that they occupy both dominant and subordinate positions on different dimensions of class structure. What is new is Wright's claim that these dimensions should be conceptualized as relations of exploitation based on differential ownership of productive assets, rather than as differential control over various elements of the production process. Descriptively the new theory also yields roughly equivalent class groupings. On the boundaries of the working class stand two kinds of contradictory class locations. The first are salaried managers, which Wright now distinguishes by their ownership of organization assets rather than by their control over the physical means of pröduction and the labor of others. Second are various nonsupervisory intermediaries (mainly salaried professionals and technicians), which Wright once distinguished by their autonomy, but now argues are distinguished by their ownership of skill assets.

Wright argues that this new formulation has advantages over his earlier theory of contradictory class locations. First, it dispenses with the problematic notion of autonomy as a criterion of class position. Second, Wright argues, by reconceptualizing the different dimensions of class structure as relations of exploitation, the new model enables him to specify the class interests of intermediate classes more clearly. Their interests both within capitalism and with respect to various noncapitalist alternatives can now be analyzed in terms of "their material optimizing strategies given the specific kinds of assets they own/control" (Wright, 1985:91). The prospects for class alliances between salaried intermediaries and either capitalists or workers can thus be derived in a more straightforward fashion from the nature of their class location. Finally, Wright argues that the new theory has a stronger historical thrust in that, by recombining the component dimensions of exploitation in different ways, it is possible to conceptualize a variety alternative class structures which may be viewed as potential successors to capitalism. "Bureaucratic statism," for example, is understood by Wright as a class society in which the ownership of organization assets becomes the dominant form of exploitation, while "socialism" is understood as a society in which both private property and organization assets have been democratized and skill differentials remain the only basis of exploitation.

These are certainly worthwhile aims of any Marxist theory of class structure. Wright is also correct, I believe, that the incorporation of relations of domination and subordination into the Marxist definition of class tends to undermine the distinctiveness of the concept. In the abstract, the development of a more elaborate model of exploitation relations would seem to be a promising strategy for clarifying the class position of salaried intermediaries. I would question, however, whether 
the particular model proposed by Wright is indeed an advance over his earlier theory. On the contrary, I would argue that Wrights attempt to reassert the primacy of exploitation relations is accomplished mainly by definitional fiat and by the incorporation of concepts that are themselves at variance both with Marxism and with what we know empirically about the functioning of the class system.

Consider Wright's concept of "organization assets" as a basis of exploitation. Wright argues that the coordination of the technical division of labor is itself a source of productivity. This is plausible. He further argues that "organization" can therefore be viewed as a productive asset which is controlled by managers and bureaucrats and which enables them to exploit the labor of those who are without such assets. This claim is much more dubious. In what sense can organization be treated as an "asset" akin to property or skills? Wright admits that the asset of organization cannot be owned in the same way as property or skills; it has no existence apart from the positions within which it is exercised and cannot be transferred by its owner from one use to another. The "ownership" of organization assets is therefore indistinguishable from the exercise of hierarchical authority. Operationally, the two concepts identify identical class groupings. What then is gained by redefining the exercise of hierarchical authority as the ownership or control of organization assets?

The crucial difference, it seems to me, is that the first view treats managerial authority as a power relation which is ultimately subordinate to capitalist property relations, while the latter defines it as a separate kind of property relation. From the standpoint of class interests, the first view interprets the privileges of managers as a dividend which they reap because of their strategic importance to the process of capitalist exploitation, while the latter treats them as the fruits of a different form of exploitation which is independent of (and potentially antagonistic to) capitalist exploitation. The latter perspective, in my opinion, is problematic for at least two reasons. First, it posits a degree of conflict between capitalists and managers that is nowhere evident. Second, it assumes that the economic returns to managerial status exist only because of the contribution of managers to productivity - an assumption which becomes more tenuous the higher one goes in the managerial hierarchy and the farther one gets from direct involvement in the production process.

Wright's concept of "skill-based exploitation" poses similar problems. As with exploitation based on organization assets, Wright assumes that the rewards accruing to credentialed employees reflect the greater contribution of more skilled employees to the total social product. This is similar to the argument of human capital theory, and there is undoubtedly 
a partial truth to this proposition. But Wright's wholesale acceptance of such a viewpoint ignores a wealth of empirical evidence demonstrating the tenuousness of the relationship between credentials and productivity or between productivity and market rewards (Bowles and Gintis, 1976; Collins, 1979).

Apart from this problem, even if one assumes that credentials by and large serve as a means of restricting and certifying truly productive skills, the concept of skill differentials is still a questionable criterion by which to define classes. Like the notion of autonomy which it replaces in Wrights conceptual scheme, skill differentials are inherently gradational and, in and of themselves, imply no necessary boundaries between classes. If a salaried professional occupies a different class position than a craft worker for reasons of skill, then shouldn't a craft worker occupy a different class position than a factory operative? Here once again Wright's model begins to look more like a theory of occupational stratification than a Marxist theory of class relations.

Finally, Wright's claim that credential exploitation is independent of capitalist exploitation is open to question. Credentials (or the lack thereof) are certainly important as a mechanism mediating between class positions as "empty places" within the social division of labor and social classes as concrete collectivities with a degree of intergenerational continuity. By restricting labor market competition they may also limit the exploitation of certain occupations. But credentials are basically valueless unless they provide entry into occupational positions that entail strategic responsibilities, are not easily rationalized, and therefore command special compensation. The structure of such positions may be influenced by the distribution of skills within the labor market, but it is also and more fundamentally conditioned by the powers and interests invested in the private ownership of the means of production. The dependent status of skill-based privilege is demonstrated nowhere more clearly than when the interests of capital dictate the deskilling of once privileged occupations as a means of increasing the rate of exploitation. Like supervisory authority, credentials are better understood from the standpoint of their articulation with capitalist relations of production, than as an independent basis of privilege.

\section{Carchedi: The New Middle Class}

A simplified conception of the theory of contradictory class locations that avoids some of the difficulties of Wright's analysis is presented by Guglielmo Carchedi. Carchedi (1977) defines class positions in terms of 
three types of dichotomous social relations. (1) Ownership relations distinguish those who own the means of production from nonowners. Like Wright, Carchedi refers here to real economic ownership, which he defines as "the power to dispose of the means of production," rather than strictly legal ownership. (2) Expropriation relations distinguish those who expropriate surplus labor from those who are expropriated of surplus labor. Contrary to Poulantzas, Carchedi does not differentiate between labor which is expropriated in the form of surplus value (productive labor) and labor which is expropriated directly as unpaid labor time (unproductive labor); for the purpose of defining classes the two are treated as equivalent forms of exploitation. (3) Functional relations distinguish those who perform the "global function of capital" from those who perform the "function of the collective worker." Carchedi defines the function of the collective worker as the production of use-values (either material or nonmaterial) within a complex and differentiated labor process. The global function of capital is defined as "the control and surveillance of the labor process"- a function which is essential to the expropriation of surplus labor and which he distinguishes from the technically necessary work of coordination and unity of the production process (which is part of the function of the collective worker).

Carchedi views these three aspects as bound together in a relation in which the ownership element is dominant over the expropriation and functional elements. In the pure case, there is a correspondence between ownership, expropriation and functional relations. This correspondence determines the two basic classes of the capitalist mode of production: the bourgeoisie, which owns the means of production, expropriates surplus labor and performs the global function of capital; and the proletariat, which does not own the means of production, is expropriated of surplus labor and performs the function of the collective worker. The correspondence between these three aspects is not perfect, however. There are historical reasons, in particular, why a degree of noncorrespondence has developed between the ownership and functional elements. In the course of the capitalist development the function of the individual capitalist (control and surveillance of the labor process) has been taken over by a differentiated managerial apparatus (the "global capitalist"), while the function of the individual worker (the production of use-values) has been broken down and reorganized into a complex division of labor (the "collective worker"). This creates the possibility of a noncorrespondence between ownership and functional relations in the form of agents who, while not owning the means of production, nevertheless perform the global function of capital, or who perform in a 
varying balance both the global function of capital and the function of the collective worker. These contradictory positions - essentially salaried managers and supervisors - are classified by Carchedi as belonging to the "new middle class."

Carchedi's conception of contradictory class locations has certain advantages over Wright's initial model. First, his criteria of class position are more explicitly relational. For example, whereas Wright conceptualizes the supervisory hierarchy as a continuum of degrees of control over the means of production, Carchedi emphasizes the antagonistic relation between those whose function is to ensure the appropriation of surplus labor and those whose labor is appropriated. Second, the fact that Carchedi defines contradictory class locations exclusively in terms of a noncorrespondence between ownership of capital and surveillance of labor (and not between ownership of capital and control of the physical means of production) means that he avoids the problems associated with Wright's conception of autonomy. Compared with Wright's revised theory of class structure, Carchedi avoids the dubious separation between capitalist exploitation and managerial (organization asset) exploitation by treating the latter as a function subsumed under the dominance of the former. Similarly, the exercise of skill is treated by Carchedi as a function of the (internally differentiated) collective worker, rather than as an independent asset which confers a nonproletarian status on those who exercise it, thereby avoiding the problems I have noted with Wright's concept of skill exploitation.

Carchedi is able to avoid the conceptual difficulties of Wright's model, however, only at the cost of considerable oversimplication. The main problem with Carchedi's model is that his notion of the global function of capital is too narrow. Noticeably absent from Carchedi's conception of class relations are any forms of capitalist domination that go beyond the direct control and surveillance of the labor process. Certainly there are other forms of domination (e.g., those described by Poulantzas as the monopolization of strategic knowledge of the production process) that are also integral to the expropriation of surplus labor and should therefore be included in the global function of capital. Restricting his attention to the labor process and to those who perform the delegated capitalist function of control over the expropriation of surplus labor, Carchedi also ignores those who perform delegated capitalist functions of control over the accounting and realization of surplus value (corporate lawyers, accountants, market analysts, etc.). As Wright (1980:363) has noted, this narrow definition of the global function of capital produces some curious results. According to Carchedi's criteria, for exam- 
ple, foremen and other low-level supervisors would be placed within the new middle class, while many top corporate professionals, planners and technocrats would be classified as proletarians since they do not directly supervise the labor of others. The class position of nonsupervisory professional and technical workers is therefore something of an anomaly in Carchedi's conception of class structure.

\section{Ehrenreichs: The Professional-Managerial Class}

The final conception of class structure to be considered is Barbara and John Ehrenreichs' theory of the professional-managerial class. For the Ehrenreichs (1977:12), classes are defined by two general characteristics: (1) by a "common relation of the economic foundations of society - the means of production and the socially organized patterns of distribution and consumption;" and (2) by a "coherent social and cultural existence," including such things as a shared life-style, educational background, kinship networks, consumption patterns, work habits and ideology. The Ehrenreichs argue that in the course of capitalist development a distinctive new class has emerged, which they call the "professional-managerial class" (PMC for short). The PMC is defined as "consisting of salaried mental workers who do not own the means of production and whose major function in the social division of labor may be described broadly as the reproduction of capitalist culture and class relations" (Ehrenreichs, 1977:13). This includes both those who carry out this reproduction function in their roles as agents of social control or as producers and propagators of ideology (teachers, social workers, psychologists, entertainers, advertising copy writers, etc.) and those who do so through their performance of administrative and technical roles which perpetuate capitalist relations of production (managers, engineers, college-trained technicians, etc.). Despite the wide range of occupations included within this category and the somewhat fuzzy boundaries separating it from the ruling class above and the working class below, the Ehrenreichs maintain that the PMC nevertheless constitutes a single, coherent class. Its members share not only a common economic function, but also a common cultural existence, characterized by distinctive patterns of family life (emphasizing individual achievement), their own forms of self-organization (professional associations), their own specific ideology (technocratic liberalism), and their own institutions of class reproduction and socialization (colleges and universities).

Historically, the Ehrenreichs argue, the PMC emerged with the rise of monopoly capitalism as part of a broader transformation of capitalist 
class relations. The formation of the PMC depended upon the coexistence of two conditions which were only met during the early part of the twentieth century: (1) the expansion of the social surplus to a point sufficient to sustain a new unproductive class; and (2) the development of the class struggle to the point that a class specializing in the reproduction of capitalist class relations became a necessity to the bourgeoisie. The expansion of professional and managerial positions satisfied this need by extending capitalist control over the actual production process, creating mass institutions of social control, and reorganizing workingclass life within a framework of mass consumer culture. Forged out of the heat of class struggle between the proletariat and the bourgeoisie, the PMC is enmeshed in a complex web of partly complementary, partly antagonistic class relations. As an agent of bourgeois cultural and technological hegemony, the PMC exists "only by virtue of the expropriation of skills and culture once indigenous to the working class" (Ehrenreichs, 1977:17). It is therefore in an objectively antagonistic relation to the working class. However, as salaried employees, members of the PMC share with other workers a common antagonism to the bourgeoisie, which they confront as a limit to their professional autonomy and an obstacle to their vision of a technocratic society. The PMC is therefore also a reservoir of anti-capitalist sentiment, albeit of an elitist and reformist variety.

What is most attractive about the Ehrenreich's analysis is their attempt to weave together threads of historical, economic, and cultural analysis in a coherent account of the contradictions of middle class life and politics. Their concept of the PMC is historically grounded in the process of class struggle. Although based on relations of production, it is not limited to a description of occupational roles but extends to broader aspects of class experience. This multidimensional aspect of their analysis is its greatest strength, but it is also the source of several problems. These derive, most basically, from the eclecticism of their model of class structure and the theoretical limitations of their concept of "reproduction."

Like Mills before thern, the Ehrenreichs draw freely upon both Marxist and Weberian traditions in their analysis of the salaried middle class. From Marx they take the notion of the PMC as an economic class, defined by a "common relation to the economic foundations of society." From Weber they take the notion of the PMC as a social class or status group, defined by a "coherent social and cultural existence." Their initial definition of class assumes a correspondence between these two dimensions of class structure, yet this point is never adequately demonstrated in their analysis of the PMC. 
The Ehrenreichs are most persuasive in arguing that there exists a coherent social class, as measured by common educational background, lifestyle, consumption patterns, mobility closure, and intermarriage, that is roughly coterminous with professional and managerial occupations. They are much less persuasive in arguing that the members of this occupational group can also be viewed as an economic class in the Marxist sense or that they share a common class interest based on their relation to the means of production. The criterion given by the Ehrenreichs for assigning managers and professionals to a common economic class is that such positions are all implicated in the "reproduction of capitalist culture and class relations." This functional definition has serious shortcomings. As other critics have pointed out, there is no strict correspondence between the function of reproduction and positions within the social division of labor (Noble, 1979; Wright, 1980). The function of reproduction is not a separate task restricted to specific social positions; it is an effect of the production process in general. As Marx demonstrates in Capital, workers themselves function to reproduce capitalist class relations simply by their participation in the capitalist production process.

A further problem with the concept of reproduction is that it lends itself to a functionalist conception of social order and a teleological view of social change. Separating reproduction from production and treating it as a specialized function of a specific social agency exaggerates the self-perpetuating capacity of the system. By positing a functional effect, reproduction, as the cause of PMC expansion, the Ehrenreichs present an overly rational, almost conspiratorial, interpretation of the rise of the PMC.

This is not to say that functional criteria have no place in class analysis. Carchedi's "global function of capital," defined as the control and surveillance of the labor process, is sufficiently specific and sufficiently identified with particular locations to be a meaningful criterion of class position. The Ehrenreich's function of "reproduction," however, is too vague to serve as anything more than a terminological gloss for intuitively assigning the "PMC" label to whatever groups appear to have some modest privilege or stake in the established order.

Particularly questionable is the equation the Ehrenreichs make between the function of managers and that of nonsupervisory professional and service workers. Whatever their cultural similarities, these two groups have very different relations to both the capitalist and the working classes. The first is directly hired by capitalists, granted delegated authority over the labor process, and rewarded for their role in the appropriation of surplus. The second is frequently employed outside of capitalist 
organizations, derives what authority it exercises from the state or its claim to professional expertise, and has a much more indirect relationship to the appropriation of surplus. Wright attempts to grasp this distinction in terms of his dual criteria of supervision and autonomy (and later in terms of organization assets and skill assets), while Carchedi argues that only the first of these groups qualifies as middle class, while the latter belongs to the more skilled sector of the working class. The Ehrenreichs themselves acknowledge the importance of this distinction when they note that, historically, the deepest rift within the PMC has been "between the managers, administrators and engineers on the one hand, and those in the liberal arts and service professions on the other" (Ehrenreichs, 1977:27). It is doubtful, however, whether the significance of this rift can be clarified without going beyond the Ehrenreich's simple functional definition of intermediate class positions.

\section{Conclusion}

I would like to summarize by presenting some tentative conclusions about the class structure of American society. This will be done by addressing, in turn, each of the basic divisions which has been proposed as a boundary between the proletariat and intermediate class positions.

First, I would argue that there is no justification, empirical or theoretical, for viewing the distinction between productive and unproductive labor as a criterion of class position. It is true that most salaried intermediate positions are largely unproductive. The expansion of unproductive labor is therefore an important factor in explaining the historical growth of intermediate class positions (Nicolaus, 1970; Przeworski, 1977; Burris, 1980). The majority of unproductive workers, however, occupy class positions that are identical to those of productive workers in the sense that they neither exercise domination over other workers nor avoid the expropriation of their surplus labor.

For similar reasons, I would reject the distinction between manual and nonmanual labor as a boundary between proletarian and nonproletarian class positions. There may have been a time, early in the twentieth century, when the manual/nonmanual division did approximate a boundary between classes. The expansion and rationalization of clerical and sales occupations, however, has long since altered the class position of routine white-collar employees. At the present time, the manual/nonmanual division is better understood as an fractional division within the working class than as a boundary between classes. 
The division between supervisory and nonsupervisory positions is more appropriate as a criterion of class position. All four of the theorists surveyed agree that salaried managers and supervisors should be excluded from the working class. The clearest justification for this exclusion is provided by Carchedi who conceptualizes management as a delegated capitalist function of enforcing the expropriation of surplus labor through the control and surveillance of the labor process. Roughly similar criteria are given by Poulantzas and Wright in his original theory of contradictory class locations. Except at certain subordinate levels where supervision entails no more than technical coordination and/or the routine transmission of higher directives, managers and supervisors occupy positions which are objectively antagonistic to those of the working class, even while they themselves are subordinate to capital. Empirically, this class antagonism is confirmed by the consistency with which managers and supervisors occupy opposing positions to other salaried employees on a wide range of political issues.

Whether nonsupervisory professional and technical positions should also be excluded from the working class is a more difficult question. The various theorists surveyed propose a number of criteria by which such positions might be differentiated from the working class. Poulantzas argues that they reinforce the subordination of other workers through their monopoly of strategic knowledge. Wright argues that are autonomous from direct capitalist domination and/or exploit other workers through their disproportionate ownership of skill assets. The Ehrenreichs argue that they reproduce the subordination of workers in their roles as agents of social control and purveyors of bourgeois ideology. Each of these criteria has been criticized as inadequate to define the boundary between proletarian and nonproletarian class positions. Nevertheless, I believe that each of them captures a partial truth about the nature of intermediate class locations. Hence, it may be possible to incorporate the insights of several of these theories within a revised model of the class structure.

In analyzing the class position of salaried professional and technical workers, the crucial question we must ask is: what is the place of these positions within capitalist relations of exploitation. On this point, I believe that Wright (1985:36-37) is correct when he argues that exploitation is fundamental to the Marxist concept of class and that domination alone does not define distinctive class positions. Contrary to Wright, however, and more in line with the arguments of Poulantzas, Carchedi, and the Ehrenreichs, I believe that exploitation cannot be specified independently of the relations of domination through which it is maintained 
and reproduced. Relations of domination that are integral to the process of exploitation must therefore be included in the definition of classes. Rather than exclude relations of domination from the definition of class, we must give closer attention to the functional relation between specific forms of domination and the process of exploitation.

Most disagreements over the class position of salaried professionals and technicians boil down to a debate over whether and how such positions are integral to the process of capitalist exploitation. To sort out the issues in this debate, I would propose that we distinguish two different ways in which salaried positions might be differentiated from the working class: (1) because they are exempt from exploitation by capitalists, and (2) because they participate in and share the fruits of capitalist exploitation of workers. Although he does not express it in quite this fashion, I believe that this is the rational kernel to Wright's notion that (salaried) contradictory class locations can be grouped into two relatively distinct clusters: one which is tangential to the capitalist-worker relation and one which is intermediate between these two classes. This distinction also provides a framework for theorizing the rift which the Ehrenreichs acknowledge, but fail to explain, between "managers, administrators and engineers on the one hand, and those in the liberal arts and service professions on the other" (Ehrenreichs, 1977:27).

Managers and supervisors are typically differentiated from the working class in the latter, more antagonistic, sense. Managers exercise delegated functions of capitalist authority over the means of production and the labor process. Because of their strategic importance to the process of exploitation, and because their functions are not easily monitored in a direct and detailed fashion, managers can demand and typically receive a share of the fruits of exploitation to ensure their loyalty to the interests of capital. This pattern is confirmed by the strong association between the managerial/nonmanagerial dichotomy and the pattern of income differences among wage and salary workers. The domination managers exercise over workers is thus tied to the process of exploitation in two ways: it is delegated for the purpose of enforcing the extraction of surplus and it is typically compensated with a share of that surplus.

Poulantzas and the Ehrenreichs try to apply the same kind of argument to nonsupervisory professional and technical workers, but their concepts of the "monopolization of strategic knowledge" and the "reproduction of capitalist class relations" are stretched far beyond the range of occupations that can reasonably be viewed as integral to capitalist exploitation. Without question, some categories of nonsupervisory pro- 
fessionals occupy strategic roles with respect to the accumulation of capital (corporate lawyers, financial managers, some types of engineers). These positions ought to be viewed as functionally analogous to managers and supervisors. More commonly, however, nonsupervisory professional and technical employees are differentiated from the working class (if at all) only in the weaker sense of being relatively exempt from exploitation by capital.

This exemption is typically due to a combination of factors. Generally speaking, capitalist relations of exploitation, while rooted in the capitalist's ownership of the means of production, depend in their operation on a combination of market and domination relations. Workers must be subjected to competition from a reserve army of labor in order to drive down the value of their labor power, and jobs must be rationalized and/or subjected to surveillance in order to ensure that the labor expended exceeds the value of the wage. Salaried professionals and technicians are typically insulated from one or both of these aspects of proletarianization, thereby limiting their exploitation by capital. As Wright points out, such positions are typically characterized by the exercise of skill and/or autonomy; however, it is not skill or autonomy per se that distinguishes them from the working class - only those forms of skill and autonomy which function as a barrier to exploitation.

Of course, this distinction between salaried intermediaries who are integral to capitalist exploitation and those who are merely exempt from capitalist exploitation does not yield a sharp boundary between two mutually exclusive groups. As with any criterion of class position, there will be ambiguous and borderline cases. But this in itself does not invalidate the logic of the distinction. The greater problem lies in the fact that intermediate positions that are distinct from the standpoint of their place within capitalist relations of exploitation tend to be much more integrated at the level of social and market relations. From the perspective of the individual social agent, the main avenue of entry into to either type of intermediate class position is the possession of educational credentials. Differential access to educational credentials limits competition for privileged occupations, secures the intergenerational reproduction of nonproletarian status, and contributes to the internalization of a common culture. Herein lies the rational kernel to the Ehrenreich's notion that nonsupervisory professionals and technicians should be classified together with managers as members of a single social class. As we have seen, this model corresponds most closely to the commonsense understanding of "middle class" in our society as measured by subjective class identification. Other research has shown that, in terms 
of intergenerational mobility, friendship networks, and residential patterns, the most significant class cleavage among salaried employees is also one which places managers and professionals together on one side and all other categories of wage and salary workers on the other (Vanneman, 1977).

Nonsupervisory professional and technical positions can thus be viewed as the most contradictory of "contradictory class locations." In terms of ownership relations they resemble the working class. Nevertheless, they typically retain a degree of control over their own labor and their immediate conditions of production. This fact, together with their relative insulation from labor market competition, serves as a barrier to their exploitation by capital. From the standpoint of social and market relations, they share much in common with salaried managers. From the standpoint of their function within the social division of labor, however, nonsupervisory professionals and technicians differ from managers in that they are generally less implicated in the exploitation of workers by capital. At this level their class positions are less sharply differentiated from other wage and salary workers and their class interests are more tangential than antagonistic to those of the working class.

Viewed in this light, the shifting political alignments of nonsupervisory professional and technical employees are less confusing than they might appear. Given their dependence on credentials and other individualistic forms of market closure, salaried professionals are understandably unsympathetic toward competing (collective) closure strategies like unionization. Their social and educational background leads them to view themselves subjectively as "middle class." But, compared with managers and supervisors, their alignment on most political and economic issues is much less opposed to that of the working class. On such questions as political party preference, confidence in corporations, support for income redistribution, and support for state welfare spending, they tend to be aligned more closely to rank-and-file workers than they are to managers and supervisors.

The model of class structure advanced in this paper can thus be summarized as follows. Most wage and salary earners belong to the working class. This includes manual workers (both productive and unproductive) and routine nonmanual workers. Salaried managers and most nonsupervisory professionals, however, should be excluded from the working class. At a minimum, such positions are relatively exempt from exploitation by capital. In some cases (most clearly in the case of managers) they participate in and share the fruits of capitalist exploitation of workers. Whether these nonproletarian positions should be classified 
as a discrete intermediate class, or a more heterogeneous intermediate stratum, depends on which aspect of class relations one chooses to emphasize. From the standpoint of social characteristics and market relations, such positions are sufficiently similar to warrant their treatment as a single social class. But, from the standpoint of their location within capitalist relations of exploitation - the standpoint emphasized in Marxist theory - such positions vary considerably in the manner and extent to which they are implicated in the process of exploitation. As a consequence, the cohesion and political alignment of these intermediate class locations tends to vary according to the issue in question.

For those who desire an unambiguous model of class structure, with neatly defined categories and clear implications for political strategy, these conclusions will come as a disappointment. Although the basic outlines of the class structure are conceptually clear, we are left with somewhat imprecise boundaries between proletarian and nonproletarian class positions and between different types of nonproletarian positions. Capitalist relations of exploitation provide the ultimate litmus test for assigning class position; however, the recognition that exploitation is articulated with diverse relations of domination (both within the market and at the point of production) makes the unraveling of exploitation relations an extremely complex task. Any attempt to reduce this complex structure to a small number of readily operationalizable criteria of class position will always be open to criticism. Further theoretical work on this topic may help to resolve some of these issues. Judging from the inconclusiveness of recent debates, however, I suspect that the ambiguity of intermediate class locations is but a reflection of the real complexity of the contemporary class structure and that further advance in this area will depend as much on careful empirical study as on pathbreaking new theorizations.

\section{Notes}

The original version of this article appeared in The Insurgent Sociologist, 14:2 (Summer, 1987), pp. 5-46.

\section{References}

Braverman, Harry. 1974. Labor and Monopoly Capital. New York: Monthly Review.

Burrin, Val. 1980. "Capital accumulation and the rise of the new middle class." Review of Radical Political Economics 12(1).

Carchedi, Guglielmo. 1977. On the Economic Identification of Social Classes. London: Routledge and Kegan Paul.

- 1986. "Two Models of Class Analysis." Capital and Class 29:195-215.

Collins, Randall. 1979. The Credential Society. New York: Academic Press. 
Ehrenreich, Barbara and John Ehrenreich. 1977. "The professional-managerial class." Radical America 11(2).

Hunt, Allen. 1977. "Theory and politics in the identification of the working class." In Alan Hunt, ed., Class and Class Structure. London: Lawrence and Wishart.

Larson, Magali Sarfatti. 1977. The Rite of Professionalism. Berkeley: University of California Press.

Marx, Karl. 1967. Capital, Volume 3. New York: International Publishers.

Mills, C. Wright. 1951. White Collar. New York: Oxford University Press.

Nicolaus, Martin. 1970. "Proletariat and middle class in Marx." In J. Weinstein and D. Eakins, eds., For a New America. New York: Random House.

Noble, David. 1979. "The PMC: a critique." In Pat Walker, ed., Between Labor and Capital. Boston: South End Press.

Poulantzas, Nicos. 1975. Classes in Contemporary Capitalism. London New Left Books. Przeworski, Adam. 1977. "The proletariat into a class: the process of class formation from Karl Kautsky's the Class Struggle to recent controversies." Politics and Society 7(4).

Skotnes, Andor. 1979. "Structural determination of the proletariat and the petty bourgeoisie: a critique of Poulantzas." Insurgent Sociologist 9(1).

Vanneman, Reeve. 1977. "The occupational composition of American classes." American Journal of Sociology 44(1).

Wright, Erik Olin. 1976. "Class boundaries in advanced capitalist societis." New Left Review 98.

- 1978. Class, Crisis and the State. London: New Left Books.

- 1980. "Varieties of Marxist conceptions of class structure." Politics and Society 9(3). - 1982. "The status of the political in the concept of class structure." Politics and Society 11(3). 1985. Classes. London. New Left Books. 